\title{
Pengenalan Teknik Vertikultur dengan Media Batang Pisang sebagai Alternatif Teknik Budidaya Tanaman
}

\author{
Mahdiannoor*, Nurul Istiqomah*, dan Purna Kusumayana** \\ Program Studi Agroteknologi* dan Agribisnis**, STIPER Amuntai \\ Email : mahdi_186@yahoo.com
}

\begin{abstract}
ABSTRAK
Permasalahan yang dihadapi petani adalah tidak adanya atau berkurangnya pendapatan usaha tani mereka pada saat lahan sawah lebak terendam air selama lebih 6 bulan karena faktor iklim, kurangnya pengetahuan petani tentang alternatif usahatani yang bisa dilakukan di pekarangan untuk menambah pendapatan selama masa menunggu sawah bisa diusahakan, dan kurangnya pengetahuan tentang pemanfaatan batang pisang dalam budidaya tanaman. Tujuan kegiatan ini adalah peningkatan keterampilan petani yang tergabung dalam Kelompok Tani Ingin Maju II Desa Pasar Senin dan Sukamaju IV Desa Kandang Halang Kecamatan Amuntai Tengah Kabupaten Hulu Sungai Utara. Pengabdian pada masyarakat ini mengunakan metode penyuluhan langsung yang mengkombinasikan antara ceramah dan demontrasi plot. Hasil yang dicapai adalah pengetahuan dan ketrampilan petani bertambah dengan terbentuknya 10 demplot vertikultur pada tiap kelompok tani.
\end{abstract}

Kata kunci : Vertikultur, batang Pisang, pekarangan, kelompok tani.

\begin{abstract}
Problems faced by farmers is the lack of or reduced income their farm at the time of wetland swampy submerged in water for over 6 months due to climatic factors, lack of knowledge of farmers about alternative farming can be done in the yard to increase revenue during the waiting paddy can be cultivated, and lack of knowledge about the use of banana stems in the cultivation of plants. The purpose of this activity is to increase the skills farmers who are members of the Ingin Maju II Farmers Group Desa Pasar Senin dan Sukamaju IV Farmers Group Desa Kandang Halang, Amuntai Tengah District of North Hulu Sungai Utara Regency. This public service using direct extension methods that combine lecture and demonstration plots. While the result is the knowledge and skills of farmers to grow with the establishment of 10 demplot verticulture each farmer group.
\end{abstract}

Keywords: Vertikultur, banana stalks, yard, farmer groups.

\section{PENDAHULUAN}

Pengaruh iklim membentuk suatu lahan yang spesifik sifatnya, salah satunya lahan rawa lebak yang pembentukannya dipengaruhi oleh air.
Menurut Noor (2007), lahan rawa lebak adalah lahan yang pada periode tertentu (minimal satu bulan) tergenang air dan rejim airnya dipengaruhi oleh hujan, baik yang turun setempat maupun di 
daerah sekitarnya. Berdasarkan tinggi dan lama genangan airnya, lahan rawa lebak dikelompokkan menjadi lebak dangkal, lebak tengahan dan lebak dalam. Kabupaten Hulu Sungai Utara merupakan daerah dengan lahan rawa lebak yang mendominasi, sehingga petaninya pun merupakan petani rawa lebak. Lamanya lahan tergenang membuat pilihan petani untuk komoditas budidayanya sangat terbatas (Noor, 2007).

\section{Pada Kecamatan Amuntai} Tengah, terutama Desa Kandang Halang dan Pasar Senin didominasi oleh lahan sawah lebak yang diusahakan pada musim kemarau ketika air tidak terlalu tinggi bahkan cenderung kering, dengan komoditas andalan padi, dan palawija serta sayuran pada surjannya. Dalam selang waktu ketika lahan dalam keadaan tergenang petani tidak dapat memanfaatkan lahannya, sehingga mereka menjadi kelompok masyarakat yang kurang produktif bahkan tidak produktif.

Untuk mengisi waktu luang tersebut perlu untuk diperkenalkan pola usaha tani yang memanfaatkan lahan pekarangan di sekitar rumah mereka, dimana umumnya lahan ini tidak tergenang ataupun jika tergenang tidak dalam waktu lama. Salah satu cara dengan memperkenalkan vertikultur menggunakan batang pisang.

$$
\text { Pemilihan Kelompok Tani }
$$

sebagai mitra dalam kegiatan berdasarkan pertimbangan bahwa anggota kelompok tani adalah masyarakat tani yang lebih mudah untuk menerima hal-hal baru serta dapat menularkan pada petani lainnya (Hermanto dan Swastika, 2011).

Target kegiatan ini mitra dapat menerapkan sistem pertanian vertikultur di pekarangan dengan memanfaatkan batang pisang yang merupakan limbah pertanian sebagai media tanam, dilakukan pada saat lahan pertanian utamanya tidak dapat diusahakan sehingga dapat meningkatkan pendapatan usaha tani, yang pada akhirnya akan tercipta petani yang kreatif dan inovatif, serta mandiri secara ekonomi. Sedangkan luaran kegiatan ini adalah peningkatan keterampilan dan peningkatan pendapatan usahatani para petani yang tergabung dalam Kelompok Tani Ingin Maju II Desa Pasar Senin dan Sukamaju IV Desa Kandang Halang Kecamatan Amuntai Tengah Kabupaten Hulu Sungai Utara. 


\section{METODE PELAKSANAAN}

\section{Mitra dan Lokasi}

Kegiatan ini bermitra dan dilaksanakan dengan Kelompok Tani Ingin Maju II Desa Pasar Senin dan Kelompok Tani Suka Maju IV Desa Kandang Halang Kecamatan Amuntai Tengah Kabupaten Hulu Sungai Utara Kalimantan Selatan. Dilaksanakan dari Mei-Nopember 2016

\section{Metode Kegiatan}

Kegiatan ini dilaksanakan tiga tahap, yaitu tahap 1 penyuluhan dan tanya jawab disertai pembuatan demplot rak vertikultur dengan ketua kelompok tani, tahap 2 penyuluhan dan tanya jawab dengan seluruh anggota kelompok tani dengan disertai pembuatan demplot vertikultur sebanyak 10 rak vertikultur per kelompok tani, dan tahap 3 adalah tanya jawab dengan anggota kelompok tani mengenai berbagai kendala serta evaluasi yang ditemui dalam pelaksanaan kegiatan.

\section{Prosedur Kegiatan}

1. Penyuluhan

Untuk tahap 1 Desa Pasar Senin dilaksanakan pada 13 Mei 2016 dan Desa Kandang Halang keesokan harinya. Sedangkan tahap 2 Desa Pasar Senin dilaksanakan tanggal 8 Agustus 2016 dan Desa Kandang Halang tanggal 10 Agustus 2016. Tahap 3 dilaksanakan di Desa Kandang Halang pada 25 Nopember 2016 dan Desa Pasar Senin esok harinya. Materi tahap 1 dan2 terdiri dari pengenalan metode vertikultur dengan media batang pisang dan cara pembuatan rak vertikultur. Untuk tahap 3 materi yang disampaikan adalah evaluasi serta umpan balik dari anggota kelompok tani sebagai mitra IbM berupa beberapa permasalahan yang dihadapi dalam pembuatan rak vertikultur dengan media batang pisang.

2. Demontrasi Plot

Waktu pelaksanaan sama halnya dengan ceramah yang dilaksanakan, bedanya pada tahap 1 demplot hanya pada ketua kelompok tani, tahap 2 pada anggota kelompok tani sebanyak 10 demplot/kelompok tani dengan alat dan bahan terdiri atas rak vertikultur (kayu, paku, batang pisang, media tanah, pupuk kandang), bibit, palu, gergaji, parang, dan polibag kecil. 


\section{HASIL DAN PEMBAHASAN \\ Tahap 1}

Kegiatan penyuluhan diisi oleh Ketua Tim IbM yang menjelaskan gambaran pertanian berdasarkan musim dan keadaan lahan rawa lebak di Kabupaten Hulu Sungai Utara dimana pada musim hujan kegiatan pertanian terhenti karena keadaan air yang dalam sehingga petani biasanya mengusahakan kegiatan lain untuk mendapatkan penghasilan. Salah satu alternatif untuk mendapatkan penghasilan adalah dengan memanfaatkan pekarangan dengan menanam tanaman sayuran menggunakan teknik vertikultur.

Selain menerangkan apa yang dimaksud vertikultur juga menjelaskan prinsip teknik bercocok tanam ini dengan memanfaatkan bahan atau barang bekas dilingkungan kita yang sudah tidak terpakai lagi supaya tetap berguna seperti batang pisang yang cukup banyak dijumpai di dua desa ini, tentunya dengan memanfaatkan batang pisang yang buahnya sudah dipanen dapat dipakai sebagai tempat media vertikultur ini. Kemudian dijelaskan juga beberapa kelebihan mengapa batang pisang yang dipilih antara lain karena mudah didapat dan tidak perlu mengeluarkan biaya untuk membelinya serta batang pisang yang berair dapat menjaga media tanam dari kekeringan.

Setelah menjelaskan dan langsung tanya jawab dengan petani mengenai beberapa hal tentang batang pisang dilanjutkan dengan menjelaskan media yang baik untuk tanaman ini.

Tanah yang ditambahkan pupuk kandang dari kotoran hewan atau kompos merupakan dua media yang baik untuk bercocok tanam secara vertikultur ini. Karena di dua desa ini banyak terdapat penduduk yang beternak ayam dan itik maka dipilihlah pupuk kandang kotoran itik dan tanah lapisan atas sebagai media tanamnya.

Hal ketiga yang dijelaskan dalam penyuluhan ini adalah mengenai tanaman yang akan ditanam yaitu beberapa tanaman sayuran yang berumur tergolong pendek, produk sayurnya terutama daun dan batang dan tidak terlalu besar. Tidak hanya penjelasan namun juga seringkali petani langsung bertanya dalam kegiatan ini mengenai jenis sayur yang ditanam.

Kegiatan demo pengenalan teknik vertikultur ini di awali dengan pembuatan rak vertikultur dari kayu 
yang pemilihan dan pembuatan lobang pada batang pisang serta pencampuran media tanam telah disiapkan sebelumnya dan penanaman pada keesokan harinya. Rak vertikultur dibuat dari kayu balok ukuran $4 \times 4 \mathrm{~cm}$ dengan panjang rak $2 \mathrm{~m}$, tinggi $1,5 \mathrm{~m}$ serta lebar bagian bawah rak adalah 70 $\mathrm{cm}$, dibuat rangkap 3 atau tiga rak dengan penempatan batang pisang berturut-turut pada rak bagian atas adalah 1 , tengah 4 batang pisang dan bagian bawah 6 batang. Batang pisang yang akan digunakan dipilih yang masih bagus setelah tandan pisang di petik, berdiameter antara $15-20 \mathrm{~cm}$. Setiap batang pisang itu dibuat lobang dengan ukuran $20 \times 15 \mathrm{~cm}$ berbentuk persegi panjang dengan kedalaman bervariasi antara bagian atas dan bawah batang pisang, namun sebagai titik batasnya adalah apabila telah mencapai atau melewati empulur batang pisang dianggap sebagai kedalaman yang cukup. Untuk pembuatan lobang digunakan parang atau pisau. Setelah selesai pembuatan lobang maka batang pisang diletakkan pada rak vertikultur. Media dari tanah dan pupuk kandang kotoran itik yang telah tercampur diisi pada lobang yang telah dibuat pada batang pisang. Untuk kegiatan penanaman sayuran dilaksanakan keesokan harinya. Sayuran yang ditanam adalah benih bayam merah, bibit sawi, bawang daun dan selederi.

\section{Tahap 2}

Pada tahap 2 ini untuk materi penyuluhan masih sama dengan tahap 1 namun demplot yang dibuat tidak lagi pada ketua kelompok tani tani, namun sudah pada anggota kelompok tani dengan jumlah demplot adalah 10 buah untuk setiap kelompok tani. Disamping materi penyuluhan tentang vertikultur dengan media batang pisang juga dilengkapi dengan brosur. Pada tahap 2 ini diberikan bantuan benih sayuran serta biaya untuk pembuatan vertikultur dengan batang pisang yang meliputi untuk pengadaan rak, batang pisang dan media tanam.

\section{Tahap 3}

Pada tahap 3 ini lebih banyak dilakukan evaluasi dan pemecahan masalah yang dijumpai pada saat melakukan pembuatan rak vertikultur serta pemeliharaan tanaman serta analisis usaha tani sederhana yang akan bisa di capai dengan kegiatan ini seperti di contohkan pada brosur yang sudah diperkenalkan pada tahap 2 . 
Pada kegiatan tahap 3 ini juga terungkap masih adanya anggota kelompok tani yang baru mulai membuat vertikultur batang pisang ini karena ada kendala yang terjadi.

\section{FOTO KEGIATAN}

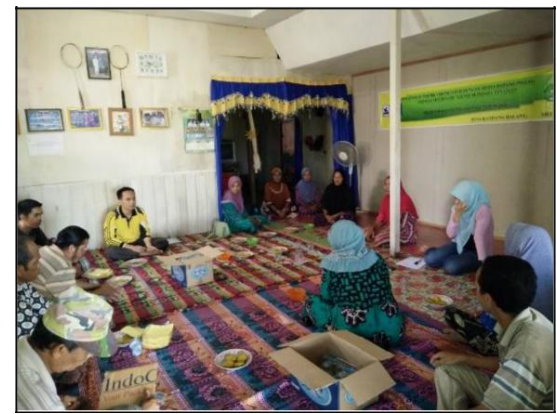

Gambar 1. Kegiatan penyuluhan Tahap 1 di Desa Kandang Halang dan Pasar Senin

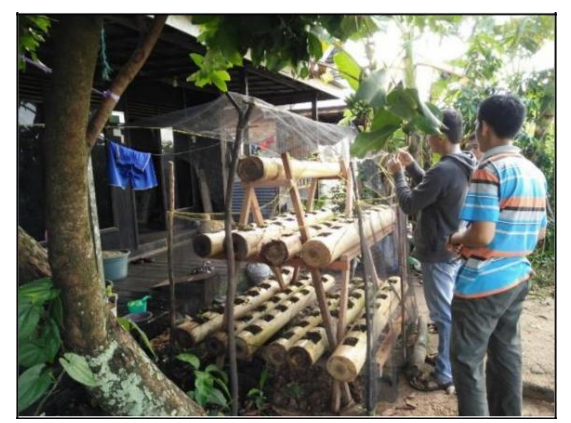

Gambar 2. Demplot vertikultur Tahap 1

Di Desa Kandang Halang

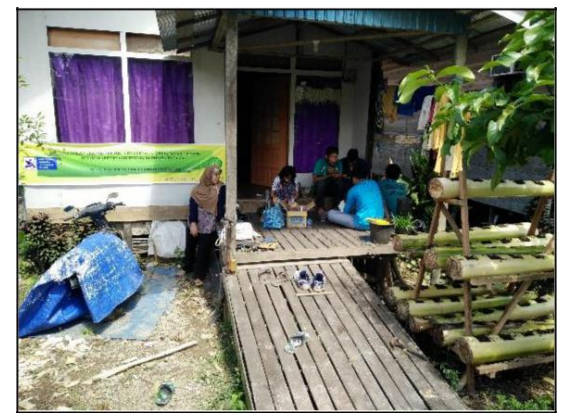

Gambar 3. Demplot vertikultur Tahap 1

Di Desa Pasar Senin

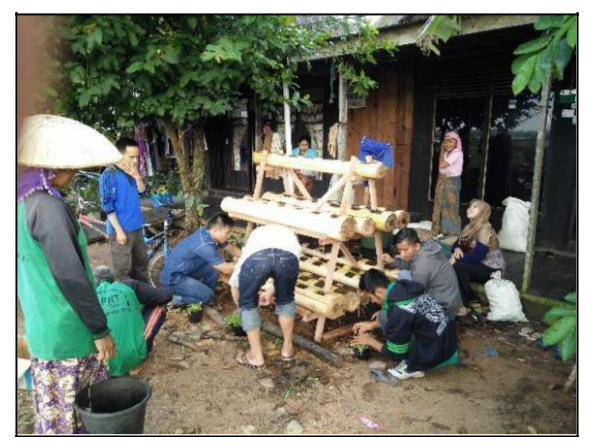

Gambar 4. Kegiatan penyuluhan Tahap

2 di Desa Kandang Halang

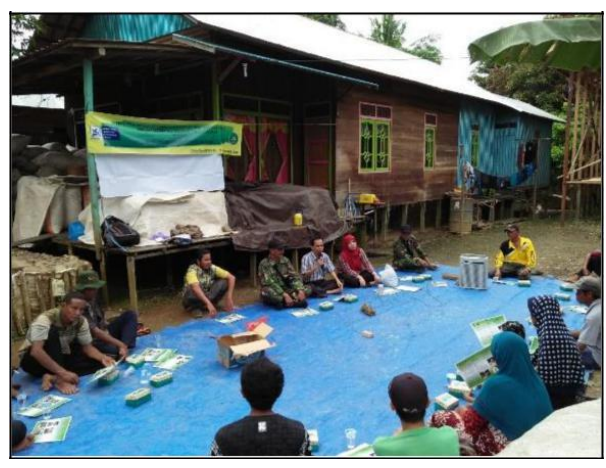

Gambar 5. Kegiatan penyuluhan Tahap 2 di Desa Pasar Senin

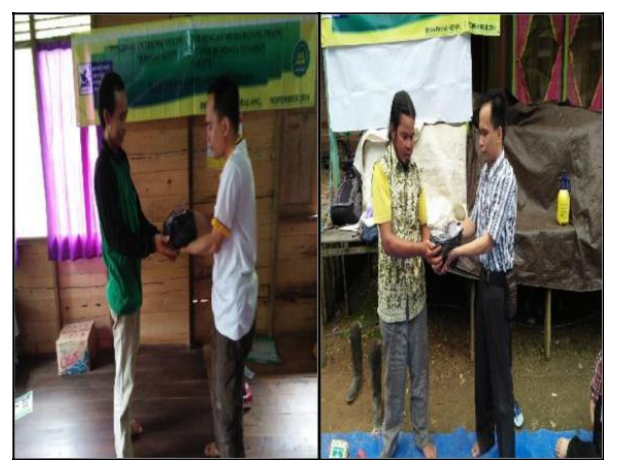

Gambar 6. Pemberian bantuan benih sayuran di Desa Kandang Halang dan Pasar Senin. 

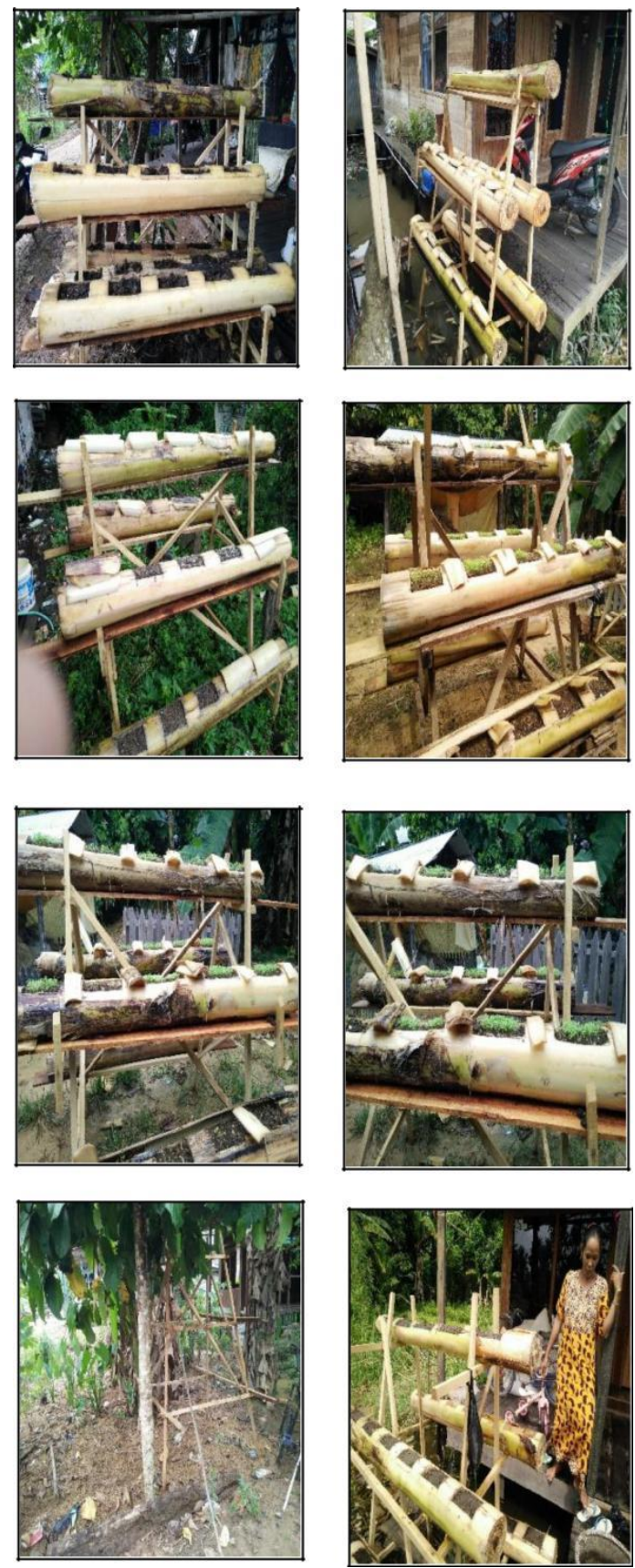

Gambar 7. Demplot vertikultur di Desa

Kandang Halang
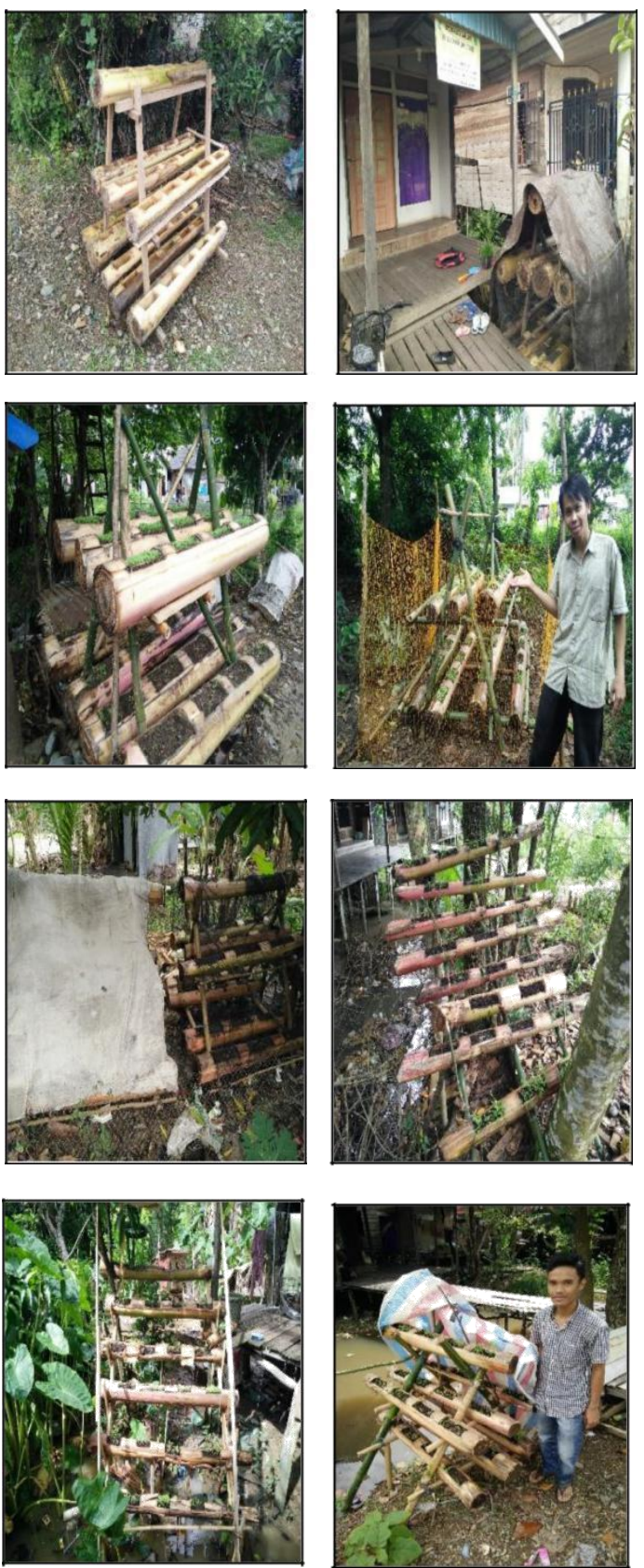

Gambar 8. Demplot vertikultur di Desa Pasar Senin

\section{SIMPULAN}

Berdasarkan hasil dan analisa pengabdian pada masyarakat penyuluhan dan demo pengenalan teknik vertikultur dengan media batang pisang sebagai alternative teknik 
budidaya untuk meningkatkan

pendapatan usahatani ini dapat

dilakukan pada dua desa mitra IbM dan

pengetahuan dan ketrampilan oetani

bertambah dengan adanya kegiatan ini.

\section{UCAPAN TERIMAKASIH}

Kegiatan IbM ini dibiayai

Direktorat Jenderal Penguatan Riset dan Pengembangan, Kementerian Riset, Teknologi, dan Pendidikan Tinggi, Kopertis Wilayah XI Kalimantan sesuai dengan Surat
Perjanjian Pelaksanaan Hibah Pengabdian Kepada Masyarakat Nomor 1055/K11/KM/2016 Tanggal 11 Mei 2016.

\section{DAFTAR PUSTAKA}

Hermanto dan Swastika, D.K.S. 2011. Penguatan Kelompok Tani : Langkah Awal Peningkatan Kesejahteraan Petani Analisis Kebijakan Pertanian. Volume 9 No. 4 hal : 371-390.

Noor, M. 2007. Rawa Lebak ; Ekologi, Pemanfaatan, dan Pengembangannya. PT. Rajagrapindo Persada. Jakarta. 